\title{
ANTHONY KENNY'S CRITICISM OF AQUI- NAS' FIRST WAY AND THE OMNE QUOD MOVETUR AB ALIO MOVETUR PRINCIPLE
}

\author{
RENATO José DE MoRaES \\ https://orcid.org/0000-0003-1777-1672 \\ Universidade Católica de Petrópolis \\ Department of Philosophy \\ Rio de Janeiro, R.J. \\ Brazil \\ renatojmoraes@gmail.com
}

\author{
Article info \\ CDD: 109 \\ Received: 03.08.2021; Accepted: 23.09.2021 \\ https://doi.org/10.1590/0100-6045.2021.V44N4.RM \\ Keywords \\ Anthony Kenny \\ Thomas Aquinas \\ First Way \\ Movement
}

Abstract: Anthony Kenny criticized the Five Ways, by Thomas Aquinas, in a widespread and influential book. About the First Way, among other critiques, Kenny considers that Thomas Aquinas failed to prove that "whatever is in motion is put in motion by another". As this principle is central for the argument developed by Aquinas on the "first mover, put in movement by no other", the First Way is insufficient and grounded on a mistake. In this article, Aristotle's and Aquinas's works are analysed to expose that their arguments about movement are sound and persuasive. On the contrary, Kenny's criticism is not consistent and is misled by bad interpretation of texts and concepts. Oderberg and Weisheipl agree with Aquinas and Aristotle, and their papers reinforce the conclusions of this article, favourable to the Medieval philosopher and against Kenny.

Manuscrito - Rev. Int. Fil. Campinas, v. 44, n. 4, pp. 202-223, Oct.-Dec. 2021. 


\section{Introduction}

In a book with essays in honour of Sir Anthony Kenny, the editors wrote that he "is one of the most distinguished and prolific philosophers of our time" (COTTINGHAM; HACKER, p. vii). Once we read some of Kenny's works, we tend to agree with this statement. He has a vast knowledge of many epochs and themes in philosophy, like Medieval thought, philosophy of mind, metaphysics, analytical philosophy, and so on.

One of his influential books is about the five ways of Thomas Aquinas. After examining Aquinas's arguments, Kenny concludes that the medieval saint failed in his attempts to prove that God exists. In his words:

"[T] he Five Ways fail [...] principally because it is much more difficult than at first appears to separate them from their background in medieval cosmology. Any contemporary cosmological argument would have to be much more different from the arguments of Aquinas than scholastic modernizations customarily are" (KENNY, p. 3-4).

Kenny's impugnation of Aquinas's Five Ways is well known by many authors and students of philosophy of religion. David Oderberg observes: "I have formed the impression that Kenny's book has had a major and lasting influence on the consensus concerning the cogency of the Five Ways". (p. 140). The consensus is certainly negative, as one might foresee.

However, just like Oderberg, I think the Five Ways are sound, logically reasonable and, more important, realistic. They all begin in the observation of reality, especially universal and evident phenomena, develop plausible reasons and 
conclude rigorously. So, they are, at the same time, simpler and stronger than critics like Kenny suggest. I recognize that some metaphysical presumptions of the Five Ways may be obscure or difficulty for some contemporary students, but they can be understood with some rewarding effort.

In this paper, I will not deal with all the Five Ways and Kenny's arguments against each one of them. My subject is the statement, defended by Aristotle and Aquinas, that "whatever is in motion is put in motion by another". This affirmation is central for the First Way, and Kenny argues that it is a false one, because based on some fallacies and misunderstandings.

On the other hand, Oderberg sustains that Kenny's attacks on that Aristotelian-Thomistic principle miss the point. In my opinion, Oderberg is fundamentally right. Nevertheless, his position does not do justice to Aquinas in one point, as I will expose. Other important article about our subject was written by Weisheipl, who sustains that the statement about movement, denied by Kenny, is almost evident, once we understand its terms.

I want to analyse the arguments of the three authors Kenny, Oderberg, and Weisheipl -, because I believe they are rich and illuminating, even when they are wrong. Moreover, they can help us to understand why some claims in philosophy of religion, especially from Scholastic thinkers, seem to be more problematic than they really are.

\section{The First Way in the Summa theologiae}

In the first part of the Summa theologiae, written around 1268, Thomas Aquinas affirms that the most manifest path to prove the existence of God is the argument from motion, which his commentators have denominated the First Way. However, in his Lectura super Ioannem (Super 
Io.), written probably between 1270 and 1272, he sustains that the most efficacious way to demonstrate God's existence is from the divine authority, that governs the whole universe (Super Io., pr. 1). This second argument resembles the Fifth Way of the Summa theologiae (S.T.).

Maybe Thomas Aquinas simply changed his mind about the best path to prove that God exists. Other explanation is that he did not consider appropriate to expose the argument based on motion in a commentary about a specific biblical text, Is VI, 1. Instead, he preferred a reasoning easily linked to Isaias's words. Anyway, it is evident that the argument from motion formulated as the First Way was dear to Thomas Aquinas, who recurred to it in different works and times.

The structure of the First Way is simple, and we can resume it in these three statements: (a) whatever is in motion is put in motion by another; (b) the series of changers and things changing cannot be infinitely long; (c) there must be a first mover, put in motion by no other, which everyone understands to be God. We find this same structure, more developed in the Summa contra gentiles (S.C.G.), I, c. 13, and more concise in the Compendium theologiae, I, c. 3.

Here, we will analyse the first affirmation, which Thomas Aquinas defended with three arguments in the S.C.G, and with only one in the S.T. Kenny seeks to refute all these arguments, which are expressly accepted and reaffirmed by Oderberg.

\section{The meaning of motus in the First Way}

Before that, it is necessary to stablish what Thomas Aquinas means by "motion", or motus, the starting point of the First Way. He writes: "It is certain, and evident to our senses, that in the world some things are in motion" (aliqua moveri in 
hoc mundo). The translation of motus and moveri to English and other modern languages is not direct nor plain.

According to Kenny, the sense of the Latin word motus is wider than that of the English word "motion" and not as wide as "change". It means change of quality, change of quantity, and change of place, and only that. This interpretation comes from Aristotle, whose Physics states that "motion can belong neither to substance nor to relation nor to agent and patient, it remains that there can be motion only in respect of quality, quantity, and place" (1. 5, c.2; 226, a, 23 $-25)$.

In its modern sense, "motion" encompasses primarily local movement, while "change" takes place whenever one tensed proposition changes from being true to being false or from being false to being true. In this wider sense, someone who starts to think, or suddenly dies, or is outgrown by a son, has a "change". But none of these examples are properly "motion" for Aquinas, as Kenny interprets him. To think about something is a mental and not a corporal event; to die is the destruction, not the change of a substance; and to have been outgrown does not mean the father changed himself (KENNY, p. 7-8).

Kenny reduces motus to some accidental changes, and clearly excludes from it substantial - generation and corruption - and changes in the soul. I believe here, at the very beginning, he weakens Thomas Aquinas's First Way, which cannot stand as Kenny presents it. Also, and more important, that is not how Aquinas formulated it. In the $\mathbf{S}$. T., he defines what he means by motion or motus in his argument: "motion is nothing else than the reduction of something from potentiality to actuality" ( $\mathrm{I}^{\mathrm{a}} \mathrm{q} .2$ a. 3 co. $)^{1}$. The concept is plainly taken in a broad sense, expressing any situation in which something in potency is reduced to actuality.

${ }_{1}$ Movere enim nibil aliud est quam educere aliquid de potentia in actum, 
Although Thomas Aquinas recognizes that sometimes we employ "motion" (motus) in a strict sense, related to accidental change in quantity, quality, and place, he also understands motus as what is common in all kinds of changes. Aristotle before him identifies these different meanings of motus, one wide, the other narrow (In Physic., lib. 5 l. 2 n. 1).

Furthermore, the definition of motus or motion, made by Aristotle, is: "the fulfilment of what is potentially, as such" (Physic., 1. 3, c. 1; 201, a, $10-11$ ). It is a broad definition, appliable to any kind of change, not only to accidental ones. Aquinas considered this definition, that in Latin is: "actus existentis in potentia secundum quid huiusmodi", as "the most appropriate" (convenientissime) (In Physic., lib. 3 1. 2 n. 3).

In fact, in many of his works, Thomas Aquinas takes this broad concept of motion. We find it in one of his first opuscules, De principiis naturae, where generation is "motus ad formam", "motion to form" (c. 1). In his comments about Aristotle's On generation and corruption, Thomas Aquinas explains that there are many kind of motions, as local motion, generation, corruption, alteration and growth. Moreover, the parts of natural science must be distinguished and ordered according to the different sorts of motions (In De generatione, pr. 1).

Therefore, the concept of "motion" in the First Way must be taken in the widest sense of any change produced by an agent. If motus were understood in the narrow sense, the sequence of movers and moved beings would end in an animated material substance or in a separated immaterial substance, which are not God. Then, the whole argument for the existence of God is pointless. If Thomas believes he has a way to God, motus encompasses every reduction of something from potentiality to actuality (WEISHEIPL, p. 29; ODERBERG, p. 147-8; WIPPEL, p. 445-7).

One of the foundations of the First Way is the conception of a universe in which every movement is related to a 
mover and a moved. Every being, except the first mover, depends on others to be moved, in any kind of change. Motus is a universal feature, and the point of the argument is that the entire movement, as a whole and in each of its parts, demands a first mover who is not moved as its principle. As the reduction of something from potentiality to actuality, motus is related to every finite being, material and immaterial.

When Kenny restricts the concept of movement, he separates a relevant portion of reality from the phenomena in which the First Way is grounded, that is, motion. This is not Aquinas's intention when he formulated his arguments. We easily notice that all the Five Ways are related to universal features of reality, common to the universe as a whole and to its parts. This is not a coincidence but stems from the dependence of every being on God, which is demonstrated in each of the Five Ways.

\section{Present movement and the simultaneous action of the mover}

In his refutation of the First Way, Kenny aims to stablish the meaning of the expression "omne autem quod movetur, ab alio movetur". He translates it as "whatever is in motion is moved by something else" and points out that we can understand it in two distinct ways. First, whatever is in motion is now being moved by something else. Second, whatever is in motion has, at some time or other, been moved by something else. This discrepancy comes from the present passive tense of the verb movetur, which means "is being moved" and also "is (at some time or other) moved" (KENNY, p. 12). In other words, the verb tense may indicate a prolongated and continuous action being held in the past, or a punctual one in the passive present.

Kenny recognizes that the second interpretation makes 
the principle more plausible. In fact, we experience situations in which the mover rests long before the moved stops its movement. A famous example is when one billiard ball hits another; the first stops, while the other continues rolling. This series of mover and moved bodies, as Kenny indicates, reaches backwards in time and is consecutive.

Here, Kenny makes a statement which is, to say the least, surprising. For him, Thomas Aquinas cannot have this kind of temporal series in mind in the First Way, because he did not think that there was anything implausible in an endless series of temporarily ordered causes. The first mover is not necessary to explain the actual movement we notice around us, if we recur to temporarily consecutive causes (KENNY, p. 12-3). Each cause is explained by the anterior one, without being necessary to recur to a first mover, as the sequence of temporarily ordered causes is endless. I used the term "cause" because Kenny employs it; however, as we are dealing with the First Way, would be better to use "mover", that is the peculiar kind of causality that produces motion. This imprecision by Kenny does not weaken his arguments.

I believe Kenny is wrong at this point. He is right when he sustains that Thomas believes there may be an infinite series of consecutive ordered causes. Nevertheless, even in such a series, the first mover is necessary to explain and substantiate the intermediary movers and moved entities. The first mover, for Thomas Aquinas, is not properly temporal, but metaphysical. If there were endless intermediary causes, a first one, in a metaphysical sense, is required to put them in motion, even if the movement has always existed. Without the first mover, that may be moving the intermediate movers for always or only from a certain moment on, there would be no movement at all (S. T., I ${ }^{\text {a }}$ q. 2 a. 3 co.).

Hence, even in the world has existed forever, a first mover, or a first cause, is necessary. Consequently, when Thomas indicates that temporal ordered movers or causes 
can reach backwards indefinitely, this does not mean these series do not require a first mover. So, Kenny's argument against the second interpretation of the principle, according to which something may be in movement even if its mover now rests, cannot be sustained.

Besides, Thomas Aquinas does not differentiate between temporarily ordered series of causes or movers and simultaneous series of movers and moved entities. The reason is simple: the principle omne quod movetur, ab alio movetur is applied to any kind of series, consecutive or simultaneous. Once again, Kenny tries to limit the range of Thomas's First Way, but the argument is better understood without these limitations.

Moreover, if the author of the First Way does not make any distinctions or exceptions in his reasonings - on the contrary, he formulates wide and universal premises -, the commentators should not propose by themselves such distinctions or exceptions. Thomas Aquinas wrote about movers and moved ones, as the latter depend necessarily on the former. So, in any sort of movement, simultaneous or consecutive, this principle has place.

It is the same reasoning we proposed when we analyzed the definition of motion: as the author neither distinguishes nor makes exceptions, the commentators must be extremely cautious when proposing doing them. The tendency to understand a philosopher in a narrower sense may be a useful habit to avoid mistakes and to search for precision. However, it may lead to equivocations when it distorts the formulated arguments.

Coherent to his position, Kenny considers that we must understand the principle as meaning "that everything in motion is being moved by something simultaneously in motion". The example provided by Thomas Aquinas for a series of movers - one hand that uses a stick to moves forward a stone - contemplates simultaneous actions of movers and 
moved ones. Furthermore, Kenny reinforces his position with an Aristotle's passage from the Physics (1. 7, c. 1; 242, a, 58), quoted by Aquinas in the S.C.G. (lib. 1 cap. 13 n. 12), which explicitly affirms that "the motion of the mover and the motion of the moved must proceed simultaneously".

However, Aristotle admits this simultaneity as a hypothesis, not as something true and proved. Thomas Aquinas presents this idea with the same goal, that is, to develop an argument to demonstrate that the chain of intermediary and corporal movers and moved cannot regress to the infinite, because then all this infinite number of things would be bodies, since whatever is moved is divisible and corporal. In this context, Thomas affirms that "omne autem corpus quod movet motum, simul dum movet movetur". In fact, any material body, to move, must be in motion. But this does not mean that, while the moved is in motion, the mover needs to be simultaneously moving. It only implies that the mover, as a material body, must have been moved to be able to move another body. In the cited text by Thomas Aquinas, simul is better translated as "likewise", and not as "at the same time". This second option is acceptable, if correctly interpreted as the movement passing from one body to the other, and in this sense being in part simultaneous.

The interpretation I propose is consistent with the verb tenses employed by Thomas Aquinas and Aristotle to express the principle we are studying. As James Weisheipl points out, Thomas Aquinas never wrote Omne movens ab alio movetur, with an active and present sense of movens; instead, he said that Omne quod movetur ab alio movetur, where the passive sense is obvious. So, an actual movement does not require and actual mover, it is sufficient a past mover. Aristotle, in turn, utilized the Greek verb kinoumnou, which is middle and passive in form and it means "is being moved", the same as movetur in Latin. Again, the active sense of movens is out of question (WEISHEIPL, p. 29). 
On this path, we can understand better why the Aristotelian principle of movement is not invalidated by the laws of inertia and universal gravitation, and modern Physics in general, even if many important commentators believe so. Historians and philosophers like Peter Duhen (p. 174-5) and Ross (p. 722) consider that Aristotle sustained that everything that is moving must be moved by something here and now conjoined to the moving body. One possible fundament for this interpretation is a passage from Physics, which was translated as "the first mover of a thing (...) is always together with that which is moved by it (by 'together' I mean there is nothing between them)" (1. 7, c. 2; 243, a, 32 - 34). In this text, "together" comes for ama, which also means "at once", "at the same time", "together with" (LIDDELL; SCOTT; JONES, 1940).

For Thomas Aquinas, this passage of the Physics does not imply that "mover and moved are together that, when one body is moved by another, they must both be at the same place". Exactly to prevent this misunderstanding, Aristotle explained that "together" (simul) is taken in the sense that nothing is intermediate between the mover and the moved (In Physic., lib. 7 1. 3 n. 1). It does not imply complete simultaneity between mover and moved, neither that they are always "in touch" or "contiguous" during the movement.

Of course, Aquinas and Aristotle did not foresee that two bodies can attract each other even if they are not contiguous nor in contact, as now we know thanks to Newton and the law of gravitation. However, this does not lead to the conclusion that they considered necessary the actual conjunction between mover and moved in any notion. On the contrary, Aquinas's commentaries on the Physics reinforces the interpretation that the movements of the mover and the moved need not to be simultaneous.

This is even clearer when he argues about the motion of light and heavy bodies. Light bodies move upwards, and 
heavy bodies downwards, because their own natures are principles of motion, although not movers by themselves. So, these bodies do not need to be moved by something else impelling them, as it is necessary in the case of a thing violently moved (In De caelo, lib. 3 1. 7 n. 9).

After having analyzed these passages from Thomas Aquinas's works, it should be certain that the simultaneity in movement between mover and moved is not required. One thing can be moved, continue his movement while the mover has already rested. That is according to observation, even if we did not know the law of inertia, and surely was noticed by Aristotle and Aquinas.

Once we understand this, the principle omne quod movetur, ab alio movetur is not dismissed as something outdated by modern Physics. It can be harmonized with our science once we do not mutilate its meaning and scope.

\section{Motion and the reduction from potentiality to actual- ity}

In his book, Kenny intends to refute three proofs that Thomas Aquinas adduces about the principle "everything that is moved, is moved by another". The three proofs are directly inspired by Aristotle, and the third is founded in the definition of movement (S. C. G., lib. 1 cap. 13 nn. 5 - 10). Only the third one is in the $\mathbf{S}$. $\mathbf{T}$., probably because Thomas Aquinas considered it sufficient to prove his reasoning.

When the terms of the principle about the movement are understood, the principle is almost immediately gasped, at least by the wise men. It becomes an almost evident principle, which imposes itself for its metaphysical and logical necessity. If so, the principle is not properly "proved", but "understood" by its own strength. This is the essence of the third "proof" of the S. C. G., retaken at the S. T. 
In the explanation of the terms of the principle, Thomas Aquinas states that nothing can be in act and in potency in respect of the same thing. Whatever is in motion, as such, is in potency, because, as Aristotle defines, motion is the act of that which is in potency, as such. On the other side, the mover, as such, is in act, for anything acts while it is in act. Therefore, nothing is both mover and moved in respect of the same movement. In conclusion, nothing moves itself (S. C. G., lib. 1 cap. 13 n. 9).

In a more developed account, Thomas writes that whatever is in motion, it is in potentiality towards something, which it does not possess. If it possesses this something, it would not be in potency towards it, but it would actually have it. Consequently, it would not be in motion, because motion is simply the reduction of something from potentiality to actuality. Besides, only something in a state of actuality can move other things, actualizing what is potential. If you are not actually something, you cannot actuate in virtue of this something. As it is not possible the same thing be at once in actuality and potentiality in the same respect, having and not having a certain feature at the same time. Therefore, it is impossible for a thing to be, in the same respect and in the same way, both mover and moved, that is, capable of moving itself (S. T., I I $^{\text {q. }} 2$ a. 3 co.).

Apprehended in its totality and simplicity, the principle cannot be successfully refuted. Not in virtue of a logical impossibility, but because it expresses necessary consequences from sound definitions, based on the reality we observe every day. It is a kind of axiom, requiring sense experience and a careful analysis of its terms to be understood. Accordingly, in late Middle Ages, the principle was used axiomatically in philosophical argumentation (WEISHEIPL, p. 28).

One might ask: if it is so easy to grasp the truth of the principle, why so many philosophers deny it? In part, because we are trained in contemporary philosophy not to 
accept anything as evident and obvious. So, we cannot accept that the apprehension of the terms leads to strong and certain conclusions outside the logical dimension. At least, I believe this is one of the reasons that Kenny discards the principle, with arguments that distort and impoverish its meaning, and at the same time complicate it.

For instance, Kenny discusses largely about motion per se and per accidens. He defends that, when he is sitting in his typewriter, he is in motion per accidens, because his fingers are in motion per se and moving him (KENNY, p. 13-5). However, in an explicit way, Aristotle and Thomas Aquinas differentiate between motion per accidens and motion or change without qualification. In the latter, a thing is said to change because something belonging to it changes (ARISTOTLE, Physics, 1. 5, c. 1; 224, a, 19 - 26; AQUINAS, In Physic., lib. $51.1 \mathrm{n} .2$ ). This is the case of the typewriter and his fingers: this is not a motion per accidens, as Kenny affirms, but a change without qualification. It is right to say that typewriter is in motion, as part of him, his fingers, are moving. But one cannot conclude from this that he is being moved by his fingers. This kind of confusion involving central concepts and notions turns difficult for Kenny to understand Thomas Aquinas's and Aristotle's arguments.

Another example of misunderstanding is Kenny's affirmation that if a thing cannot be moved by itself, it does not follow that it must be moved by something else. He asks: "Why cannot it just be in motion, without being moved by anything, whether by itself or by anything else?" (p. 18-9). But this is exactly what Thomas Aquinas, based on Aristotle, is trying to prove: if something has moved, it was moved by something else which is in actuality. This conclusion is necessary from the meaning of the terms involved.

For Aristotle, Aquinas, and many classical philosophers, it makes no sense to realize that something is moving, cannot be moved by itself, and not to conclude that something else 
is its mover. Kenny's question is logically possible, but not metaphysically sustainable. It evades the problem, that if the movement cannot be made by the moved alone, a mover is required.

According to Kenny, the principle omne quod movetur, ab alio movetur needs to be completed with a proof that whatever is in motion is being moved. He suggests that Thomas Aquinas perhaps missed this flaw because the Latin word movetur has double and means both "is in motion" and "is being moved" (KENNY, p. 19). But as we analyzed before, neither Aristotle nor Aquinas defended that whatever is in motion is being moved at the same time. For them, something may be in motion without a simultaneous mover. As Kenny does not comprehend that, his question is understandable; but it is out of place, because any motion, being the reduction of something from potentiality to actuality, requires a mover. Not necessarily a simultaneous one, but definitely one mover.

\section{What means the actuality of the mover}

Another argument Kenny makes against the principle of the First Way is instigating. Thomas Aquinas writes: "a thing cannot be brought from potentiality to actuality except by something which is itself in actuality. Thus, something which is actually hot, like fire, makes something which is potentially hot - say wood - to be actually hot" (S. T., I a $^{\mathrm{a}} 2$ a. 3 co.). Kenny points out that the principle that "only what is actually F will make something else become F does not seem universally true", as Thomas Aquinas presents it.

The English philosopher remembers that a kingmaker does not need to be a king, dead men do not commit murders, and a man who fattens oxen do not need to be fat himself. Although the principle can be applied in the example of fire, or when someone dries himself with a dry towel, not 
only what is in actuality can move something from potentiality. Even electric heaters can heat up without electricity being hot itself, and friction, not being hot itself, produces heat (KENNY, p. 21-2).

For Kenny, the dismiss of this principle invalidates the whole argument about the impossibility of something being moved by itself. As something which is only potentially $\mathrm{F}$ can reduce others to $\mathrm{F}$ in actuality, there is no reason why the moved itself, that is potentially, cannot reduce itself to actuality (KENNY, p. 22-3).

Oderberg examines Kenny's arguments and thinks they are relevant. One way to overcome them is to suppose, as MacDonald does (MACDONALD, p. 134-5), that is only required that "the immediate cause of a thing's entering in state $S$ be itself in a state of actuality respect to $S$ that is 'sufficient' to bring about the change", being sufficiency explained in terms of greater degree, greater perfection, or some allied notion (ODERBERG, p. 160).

For Oderberg, it is no small matter to interpret Aquinas's arguments in a non-circular, non-question-begging and yet in a meaningful way. To do so, he states that all that Aquinas requires is that the change of anything from being potentially $F$ to actually $F$ requires some distinct actuality to bring about the change (ODERBERG, p. 160-1). So, the demand of some likeness between mover and moved is weakened. Although Oderberg concludes that the arguments from potentiality to actuality is strong and is immune to many counterexamples Kenny raises, I believe that Oderberg concedes too much to his counterpart.

Thomas is right when he writes that "in a proper generator, the likeness of the thing generated must exist in some way". As we can see, it is not only "some distinct actuality", but some likeness of the generated thing exists in a proper generator (Sententia Metaphysicae, lib. 7 1. 8 n. 13). In the case of the fire and the heat produced by it, the likeness is 
evident. In others, the similitude between mover and moved is not so clear, but it will be present at least to a certain extent.

Aristotle and Thomas Aquinas realize and explain the different sorts of generation or movement, according to different ways in which the thing generated is like the thing which generates it (ARISTOTLE, Metaph., 1. 7, c. 9; 1034, a, $22-$ 30). Concretely, Thomas Aquinas discriminates between things generated by others properly or accidentally. Something generated by other accidentally is not generated by the generator because this is of a determined kind. Hence, the generated does not need to have any likeness to the generator. Thomas exemplifies this with the discovery of a treasure, which has no likeness in who discovers it accidentally when he was digging to plant something.

Of course, only someone who can know something is able to discover something. Discovery, in the example, is simply to know that the treasure exists. We might say that the treasure is discovered by someone who can actually know, by his senses and intelligence. Without this actuality in the agent, the treasure could not be reduced from the potentiality to the actuality of being discovered. So, we might argue that the likeness between mover and moved, however tenuous, is present, as we have a knower, and something known. After all, the soul becomes intentionally what it knows, bringing what is exterior to within the agent. However, Thomas Aquinas does not recognize or refer to such similitude. On the other hand, when the generation is proper, the likeness of the thing generated must in some way exist in the generator.

The proper generation occurs in three ways. First, wholly univocal, when the form of the thing generated preexists in the generator according to the same mode of being, and in a similar matter. That is what happens when fire generates fire or man begets man. Second, partly univocal and partly 
equivocal. In these cases, the form of the generated preexists in the generator, but not in the same mode of being nor in a substance of the same kind. That is how the form of a house preexists in the builder: as an immaterial being in his mind. Therefore, this type of generation is univocal from the standpoint of form, and equivocal from the standpoint of how the form is in the subject. Third way, not univocal in any way. In this kind of proper generation, only some part or a part of a part of the thing generated preexists in the generator, and not its whole form. In the heated medicine, preexists the heat that is a part of health, or something leading to a part of health (Sententia Metaphysicae, lib. 7 1. 8 n. 14-6).

With these distinctions and explanations that Thomas Aquinas provides, Kenny's counterexamples and reasonings, against the principle that only what is in actuality reduces other from potentiality, weaken and are no longer convincing. For the problem of heat caused by motion, Thomas Aquinas himself had answered it, when he writes that "heat is present in a sense in the motion itself, as in an active power. For the power of causing heat which is in motion is itself belonging to the genus of heat". Therefore, the heat which is present virtually in motion causes the heat in the body by an equivocal generation, for the heat in motion and in the heated body are not of the same nature (Sententia Metaphysicae, lib. $71.8 \mathrm{n}$. 18). This is the third way of proper generation, as in the cases of the kingmaker and the man alive that kills someone.

The kingmaker is an instrument for the political society to crown a king or queen. So, he is not necessarily king himself, although he has an active power, given by the political order, to designate the new governor. For the case of the killer, he does not need to be dead to kill. His action - v. g., to give a shot or stab with a knife -, is a movement that damages tissues, organs or bones of the victim. It is a simple kind of local movement, whose effect is to kill the victim. As we 
can see, it is not difficult to realize how something in actuality reduces something in potentiality in these situations, as a proper generator or mover.

\section{Conclusion}

One of the strengths of the First Way is its simplicity and conciseness. Anyone can disagree with that, for sure, especially if he does not accept some of the metaphysical presuppositions of Thomas Aquinas. However, to refute this proof of God's existence, we need first to understand its arguments under the best light possible, as a rule of interpretation. Moreover, it is important not to complicate or obscure the notions and concepts as formulated by Thomas Aquinas.

The central problem with Kenny's confutations of the principle omne quod movetur, ab alio movetur it that he is not really facing Thomas' thought, but a distorted and weakened version of it. In its original version, with its universal claims, clear concepts, and foundation in reality, the principle is "supposed to be a metaphysical certainty the denial of which would be conceptually incoherent" (FESER, 2010).

In this paper, I did not contemplate all Kenny's arguments against the principle on movers and moved entities. But I hope to have demonstrate that his reasons are not as strong as they may seem at first sight. Rather, at the end of the analysis, I believe we are much better situated - with sound notions, a coherent view of movement, and a convincing explanation on the relationships of entities in terms of actuality and potentiality - by the side of Aquinas and Aristotle than with Kenny and other deniers of the First Way. 


\section{References}

ARISTOTELE. Fisica: testo greco a fronte. Introduzione, traduzione e noti di Roberto Radice. Roma: Bompiani, 2011.

ARISTOTELES. Metafísica. Introducción, traducción y notas de Tomás Calvo Martínez. Madrid: Gredos, 2003.

ARISTOTLE. The complete works of Aristotle: the revised Oxford translation. BARNES, Jonathan (ed.). Princeton: Princeton University Press, 1991. t. 1: 1757 p.; t. 2: $1644 \mathrm{p}$.

FESER, E. Aquinas: a beginner's guide. Oxford: Oneworld Publications, 2009.

KENNY, A. The five ways: St. Thomas Aquinas' proofs of God's existence. New York: Routledge, 2003.

MACDONALD, S. “Aquinas's parasitic cosmological argument”. Medieval Philosophy and Theology 1: 119-55, 1991.

ODERBERG, D. S. "Whatever is changing is being changed by something else': a reappraisal of premise one of the First Way". In: COTTINGHAM, J.; HACKER, P. (ed.). Mind, method, and morality: essays in honour of Anthony Kenny. Oxford: Oxford University Press, 2010. p. 140-64.

Sancti THOMAE DE AQUINO. Commentaria in octo libros Physicorum. Textum Leoninum Taurini 1954 editum ac automato translatum a Roberto Busa SJ in taenias magneticas denuo recognovit Enrique Alarcón atque instruxit. Disponível no sítio www.corpusthomisticum.com, editado por ALARCÓN, Enrique. Último acesso em 2 de julho de 2021 (cit. In Physic.). 
Sancti THOMAE DE AQUINO. Sententia libri Metaphysicae. Textum Taurini 1950 editum ac automato translatum a Roberto Busa SJ in taenias magneticasdenuo recognovit Enrique Alarcón atque instruxit. Disponível no sítio www.corpusthomisticum.com, editado por ALARCÓN, Enrique. Último acesso em 2 de julho de 2021 (cit. Sententia Metaphysicae).

Sancti THOMAE DE AQUINO. Summa contra gentiles. Textum Leoninum emendatum ex plagulis de prelo Taurini 1961 editum ac automato translatum a Roberto Busa SJ in taenias magneticas denuo recognovit Enrique Alarcón atque instruxit. Disponível no sítio www.corpusthomisticum.com, editado por ALARCON, Enrique. Último acesso em 2 de julho de 2021 (cit. S. C. G.).

Sancti THOMAE DE AQUINO. Summa Theologiae. Textum Leoninum Romae 1888 editum ac automato translatum a Roberto Busa SJ in taenias magneticas denuo recognovit Enrique Alarcón atque instruxit. Disponível no sítio www.corpusthomisticum.com, editado por ALARCÓN, Enrique. Último acesso em 2 de julho de 2021 (cit. S. T.).

Sancti THOMAE DE AQUINO. Super Evangelium S. Ioannis lectura. Textum Taurini 1952 editum ac automato translatum a Roberto Busa SJ in taenias magneticas denuo recognovit Enrique Alarcón atque instruxit. Disponível no sítio www.corpusthomisticum.com, editado por ALARCÓN, Enrique. Último acesso em 2 de julho de 2021 (cit. Super Io.).

WEISHEIPL, J. "The principle omne quod movetur ab alio movetur in Medieval Physics”. Isis 56 (1): 26-45, 1965. 
WIPPEL, J. F. The metaphysical thought of Thomas Aquinas: from finite being to uncreated being. Washington D.C.: The Catholic University of America Press, 2000.

$(c)$ BY

Manuscrito - Rev. Int. Fil. Campinas, v. 44, n. 4, pp. 202-223, Oct.-Dec. 2021. 